\title{
Rhodamine B accumulation and MXR protein expression in mussel blood cells: effects of exposure to vincristine
}

\author{
C. Minier*, M. N. Moore \\ Molecular Cell Biology and Pathology, Plymouth Marine Laboratory, Citadel Hill, Plymouth PL1 2PB, United Kingdom
}

\begin{abstract}
Mussel hemocytes accumulate rhodamine B within their lysosomal compartment. This intracellular retention, detected and quantified by computerised confocal microscopy, is enhanced by the presence of verapamil. Study of 2 different populations showed alteration in rhodamine B retention and simultaneous differential expression levels of proteins immunorelated to the multidrug resistance (MDR) transporter in relation to their environment. Chronic exposure of animals to the Vinca antitumor alkaloid vincristine causes the hemocytes to accumulate less rhodamine $B$, to be more sensitive to verapamil and to express more MDR-related proteins. These data add consistency to previous results on multixenobiotic resistance in mussels.
\end{abstract}

KEY WORDS: Multixenobiotic resistance $\cdot$ MDR Mussel $\cdot$ Rhodamine $\cdot$ Vincristine

\section{INTRODUCTION}

Cells exhibiting the multidrug resistance (MDR) phenotype generally show the following properties: (1) over-expression of the MDR gene product, a membrane glycoprotein of molecular weight approximately $170 \mathrm{kDa}$ (Juliano \& Ling 1976); (2) decreased intracellular drug accumulation due to both an active outward transport of broad specificity and decreased intracellular influx (Gottesman \& Pastan 1993); and (3) lack of responsiveness to a collection of natural and synthetic toxic compounds that includes antitumor alkaloids isolated from Vinca rosea, anthracyclines and rhodamine 123 (Tapeiro et al. 1984, Riordan \& Ling 1985). This resistance can be circumvented, to a variable extent, by inhibitors such as verapamil, calmodulin inhibitors or drug analogues (Cornwell et al. 1987, Hamada et al. 1987).

Several studies have shown that this phenotype, or part of it, is not restricted to mammalian multidrug

\footnotetext{
- Present address: Laboratoire d'Ecotoxicologie, Faculté des Sciences, 25, rue Philippe Lebon, BP 540, F-76058 Le Havre Cedex, France. E-mail: minier@fst.univ-lehavre.fr
}

resistant cells but is part of a highly conserved system with possibly different implications among the whole living world. Indeed, genes from bacteria, plants, yeast, invertebrates and non-mammalian vertebrates have been found to share a high degree of identity with the mammalian MDR genes, thus constituting the $A B C$ (ATP-binding cassette) superfamily (Ames et al 1990, Higgins 1992). As for marine invertebrates, a 300 bp long fragment from the marine worm Urechis caupo has been recently sequenced and identified as a member of the MDR gene family (Toomey 1995). Other work has also shown evidence for the expression of one or several immunorelated membrane proteins in U. caupo (Toomey \& Epel 1993), in the mussels Mytilus edulis, $M$. galloprovincialis and $M$. californianus and the oyster Crassostrea gigas (Minier et al. 1993, Cornwall et al. 1995, Galgani et al. 1995), in the clam Corbicula fluminea (Waldmann et al. 1995), in the marine snail Monodonta turbinata (Kurelec et al. 1995) and in the sponges Geodia cydonium and Verongia aerophoba (Kurelec et al. 1992). Furthermore, decreased accumulation of fluorescent or radioactive MDR dyes such as rhodamine $\mathrm{B}$ and ${ }^{3} \mathrm{H}$-vincristine has been measured and shown to be verapamil sensitive (Kurelec 1992, Toomey \& Epel 1993). In U. caupo the protein 
detected by the anti-MDR protein monoclonal antibody C219 has been identified as the protein that can bind several MDR substrates, including forskolin, verapamil and rhodamine B (Toomey \& Epel 1993). All of these data indicate that several marine organisms possess a molecular system similar to the one responsible for the multidrug resistance of mammal cells. The third characteristic of MDR cells, i.e. tolerance to toxic compounds, has therefore been proposed as a protective function for this mechanism. As this mechanism would be expressed in response to environmental xenobiotics, it has been termed multixenobiotic resistance (MXR). This idea is supported by the observation that the cited organisms can grow and reproduce in polluted areas. Field studies have also shown differential expression levels of the C219 detected protein among sites of differential pollution levels (Minier et al. 1993). In addition, pesticides, sea water and sediment extracts can competitively inhibit the decreased accumulation of rhodamine $B$ or vincristine and their binding of cells expressing these MDR-like characteristics (Kurelec 1992, Toomey \& Epel 1993). Finally, exposure to polluted water and diesel oil has been reported to increase the expression of the MXR characteristics of the marine snail $M$. turbinata (Kurelec et al. 1995).

The aim of this work was to investigate the effects of a well known M.DR inducer, namely the Vinca alkaloid vincristine (Meyers et al. 1985), on the blue mussel Mytilus edulis. The MXR mechanism and its cellular implications were studied by assessment of rhodamine $B$ accumulation/exclusion using confocal microscopy and immunochemical measurements of MDR-like protein expression.

\section{MATERIALS AND METHODS}

Animals. Specimens of the blue mussel Mytilus edulis (shell length 4 to $5 \mathrm{cmi}$ ) vere sampled from the southern coast of Cornwall (England) at Whitsand Bay from December 1994 to August 1995 and at the Lynher estuary in May 1995. The mussels were then maintained in $10 \mathrm{l}$ filtered sea water at $14^{\circ} \mathrm{C}$

Mussels from the Lynher estuary accumulate on average $4 \mu \mathrm{g} \mathrm{g}^{-1}$ wet weight of 2 and 3 ring polycyclic hydrocarbons, whereas mussels from Whitsand Bay contain $0.4 \mu \mathrm{g} \mathrm{g}^{-1}$ wet weight of these compounds (Readman et al. 1982, Widdows et al. 1995, P. Donkin pers. comm.).

Exposure experiments. Repeated injections of a $100 \mu \mathrm{l}$ mussel physiological saline solution $(20 \mathrm{mM}$ Hepes, $436 \mathrm{mM} \mathrm{NaCl}, 53 \mathrm{mM} \mathrm{MgSO} 4,10 \mathrm{mM} \mathrm{KCl}$,
$10 \mathrm{mM} \mathrm{CaCl}$ l with or without the Vinca alkaloid vincristine (Sigma) were carried out into the posterior adductor muscle using a syringe. The first injection was of $1 \mu \mathrm{g} \mathrm{ml}^{-1}$ and subsequent ones were of 100 or $200 \mu \mathrm{g} \mathrm{ml}^{-1}$. This, assuming that the mussels used had roughly $2 \mathrm{ml}$ of blood, gave a final vincristine concentration of 5 or $10 \mu \mathrm{g} \mathrm{ml} \mathrm{ml}^{-1}$ in the mussels and corresponds to the doses used to overexpress the MDR phenotype in mammalian cell lines (Meyers et al. 1985). Different times between treatments ( 2 or $3 \mathrm{~d}$ ) and total duration ( 7 to $28 \mathrm{~d}$ ) were used in order to study time course and putative cumulative effects of exposures. These procedures are reported in Table 1.

Fluorescence imaging of cells. Hemocytes were withdrawn from the posterior adductor muscle of mussels using a hypodermic syringe into a physiological saline solution as described by Lowe et al. (1995) at least $48 \mathrm{~h}$ after the last injection of vincristine. Cells were then dispatched into siliconised microcentrifuge tubes, and rhodamine B (400 $\mu \mathrm{M}$ solution) was added to provide a final $4 \mu \mathrm{M}$ rhodamine $\mathrm{B}$ incubation medium either containing or not containing an additional $20 \mu \mathrm{M}$ of verapamil. The cells were incubated for 45 min in $4 \mu \mathrm{M}$ rhodamine $\mathrm{B}$ in the dark at $15^{\circ} \mathrm{C}$ and then transferred onto microscope slides using a cytospin centrifuge ( $8 \mathrm{~min}$ at $600 \mathrm{rpm}$ ). Images of the cells were finally taken with a laserscan confocal microscope (Sarastro, Molecular Dynamics) with settings as follows: laser line, $488 \mathrm{~nm}$; barrier filter, $530 \mathrm{~nm}$; laser strength, $10 \mathrm{~mW}$; detector settings, $1000 \mathrm{~V}$. Single cell fluorescence of the probe within at least 30 cells was measured by a computerised image analysis system (Silicon Graphics, Reading, UK)

Immunochemical studies. Mussel blood cells and gill tissues and bovine liver (collected in a nearby slaughterhouse) were sonicated twice for 5 and $15 \mathrm{~s}$ respectively at $20 \mathrm{kHz}$ in $10 \mathrm{mM}$ Tris $/ \mathrm{HCl}, 0.5 \mathrm{M}$ sucrose, $0.15 \mathrm{mM} \mathrm{KCl}, 40 \mu \mathrm{g} \mathrm{ml^{-1 }}$ aprotinin, $\mathrm{pH} 7.6$ using the MSE $150 \mathrm{~W}$ ultrasonic disintegrator (Fisons, Crawley, UK) and centrifuged for $10 \mathrm{~min}$ at $6000 \times \mathrm{g}$. Supernatant protein content was determined using the Lowry pro- 

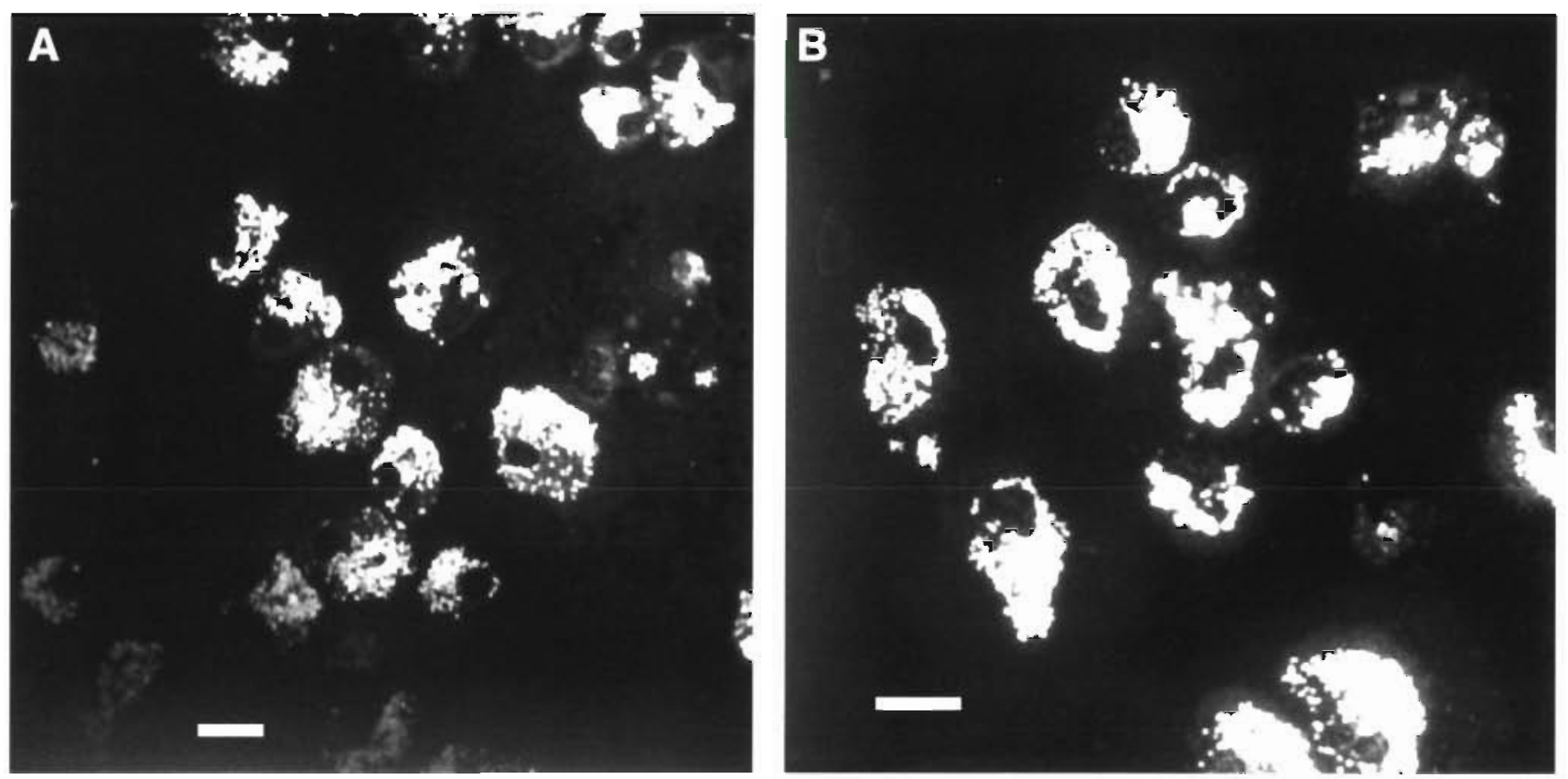

Fig. 1. Mytilus edulis. Staining pattern of blood cells from mussels living at Whitsand Bay (UK). Cells were incubated for 45 min in physiological medium containing $4 \mu \mathrm{M}$ rhodamine B either (A) without or (B) with $20 \mu \mathrm{M}$ verapamil. Scale bar $=10 \mu \mathrm{m}$

tein assay (Lowry et al. 1951) with bovine serum albumin (BSA, Sigma) as standard. Gel electrophoresis of protein extracts, diluted in an equal volume of $150 \mathrm{mM}$ Tris, pH 6.8, 4\% SDS (sodium dodecyl sulphate) (w/v), $20 \%$ glycerol (w/v), $10 \% \beta$-mercaptoethanol (v/v) and $0.02 \%$ bromophenol blue ( $\mathrm{w} / \mathrm{v})$, was performed in $3 \%$ polyacrylamide (stacking) and $7.5 \%$ polyacrylamide gels containing $0.1 \%$ SDS (w/v). Proteins were transferred to nitro-cellulose sheets (Hybond-C, Amersham) for $60 \mathrm{~min}$ at $25 \mathrm{~V}$ using the Horizblot system (Genetic Research Instruments Ltd, Dunmow, UK). Membranes were immersed in a Tris-buffered saline solution (TBS: $10 \mathrm{mM}$ Tris- $\mathrm{HCl}, 150 \mathrm{mM} \mathrm{NaCl}, \mathrm{pH} 7.4$ ) containing $2 \%$ $\mathrm{BSA}(\mathrm{w} / \mathrm{v})$ and $0.2 \%$ Tween $20(\mathrm{w} / \mathrm{v})$ for $1 \mathrm{~h}$ at room temperature, then for $2 \mathrm{~h}$ in TBS-Tween 20 with $1 \mu \mathrm{g}$ $\mathrm{Hl}^{-1}$ monoclonal anti-MDR antibody C219 (Centocor Diagnostics, Malvern, PA, USA) on a rocking platform. The blots were washed twice for $15 \mathrm{~min}$ in TBS-Tween and incubated with the second antibody solution (alkaline phosphatase-conjugated anti-mouse antibody, Sigma, diluted 2000 -fold) for $60 \mathrm{~min}$. Sheets were washed 3 times with TBS-Tween and finally with 100 mM Tris- $\mathrm{HCl}, 100 \mathrm{mM} \mathrm{NaCl}, 5 \mathrm{mM} \mathrm{MgCl}$, pH 9.5 (reaction buffer) for $10 \mathrm{~min}$. Alkaline phosphatase labelled blots were developed by incubating them with $1.25 \mathrm{mg}$ $\mathrm{ml}^{-1}$ of 5-bromo, 4-chloro, 3-indolyl phosphate (BCIP, Sigma) and $2.5 \mathrm{mg} \mathrm{ml}^{-1}$ Nitro-Blue Tetrazolium (NBT, Sigma) in the reaction buffer. Semi-quantification of the staining results was performed by an image analysis system (Kontron, Thame, UK).
Statistical analysis of data. A set of 4 to 8 images (depending on cell number appearing on each image, the total of which had to be sufficient for statistical analysis) was taken at random and stored in the Silicon Graphics computer. From these images, fluorescence of at least 30 cells was measured per hemolymph sample. Student's t-test for non-paired observations was used for comparisons between groups from different sample sites. Effects of treatments with vincristine were tested with a 1-way test with repetition of the experiment (ANOVA)

\section{RESULTS}

\section{Cellular fluorescence imaging}

Incubation of mussel blood cells in a physiologic medium containing $4 \mu \mathrm{M}$ rhodamine $\mathrm{B}$ for $45 \mathrm{~min}$ enabled the probe to cross the cellular membranes and to accumulate within the cell (Fig. 1). This pattern of fluorescence corresponds to the lysosomal compartment as indicated by comparison with neutral red distribution and thus shows how rich these cells are in lysosomes. Each cell contained approximately 50 to 300 fluorescent vesicles.

The lysosomes of untreated healthy cells localised at the centre of the cell appeared to be ellipsoidal and to be arranged in a radiant fashion from a point located at the centre of the cell next to the nucleus. Incubation of 
the cells in the presence of $20 \mu \mathrm{M}$ verapamil increased the size of the lysosomes (Fig. 1B) and induced them to adopt a more circular shape.

\section{Rhodamine B exclusion activity}

Rhodamine B accumulation within blood cells can be assessed by its fluorescence intensity. Blood cells drawn from 2 populations of mussels living in different areas showed differential accumulation rates within their lysosomes. The fluorescence intensity of cells from mussels sampled at the Lynher estuary was $29 \%$ lower than that of the cells from Whitsand Bay (Fig. 2) after incubation for $45 \mathrm{~min}$ in $4 \mu \mathrm{M}$ rhodamine B. Addition of $20 \mu \mathrm{M}$ verapamil during this incubation resulted in a $30 \%$ increase in fluorescence in both cases.

To test whether an impaired dye accumulation could be induced by exposing the animals to toxic compounds, repeated injections of the Vinca alkaloid vincristine were performed within the adductor muscle of mussels from Whitsand Bay. Several similar experiments were conducted with variations in duration and injected doses. Details of the exposure experiments are given in Table 1.

Blood cells were withdrawn from the mussels 2 $\mathrm{d}$ after the last injection and stained with rhodamine $B$, with or without verapamil. Results shown in Table 2 indicate that vincristine enhanced the ability of the treated cells to lower their dye retention within their lysosomes. This dye exclusion activity reduced the fluorescence by up to half the control value.

Enhanced dye exclusion was altered by the presence of the MDR inhibitor verapamil. Indeed, control cells accumulated $10 \%$ more dye (on average) when incubated with verapamil. This phenomon was enhanced in treated cells: the more dye exclusion activity the cells showed, the more sensitive to verapamil they were. A linear regression analysis between these 2 parameters gave a correlation coefficient $r$ equal to 0.89

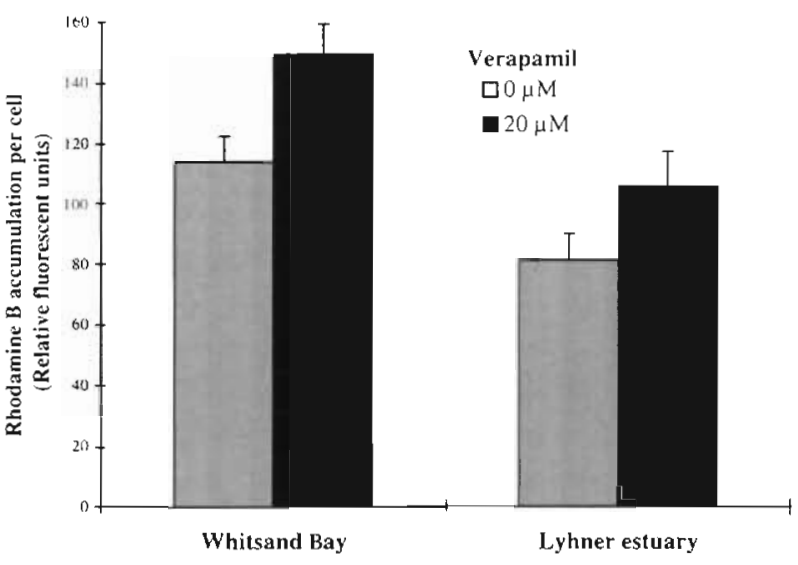

Fig. 2. Mytilus edulis. Rhodamine B accumulation in mussel blood cells from the Lynher estuary and Whitsand Bay. Bars represent confidence intervals ( $\mathrm{CI}=99 \%$ )

(n = 7) (Fig. 3). Nevertheless, it was noted that verapamil did not always restore the rhodamine concentration to the level of the control cells.

Analysis of the relation between the total dose injected in mussels during the treatments and the rhodamine exclusion activity gave a non-significant linear correlation coefficient $(r=0.68, p=0.14)$. Nevertheless

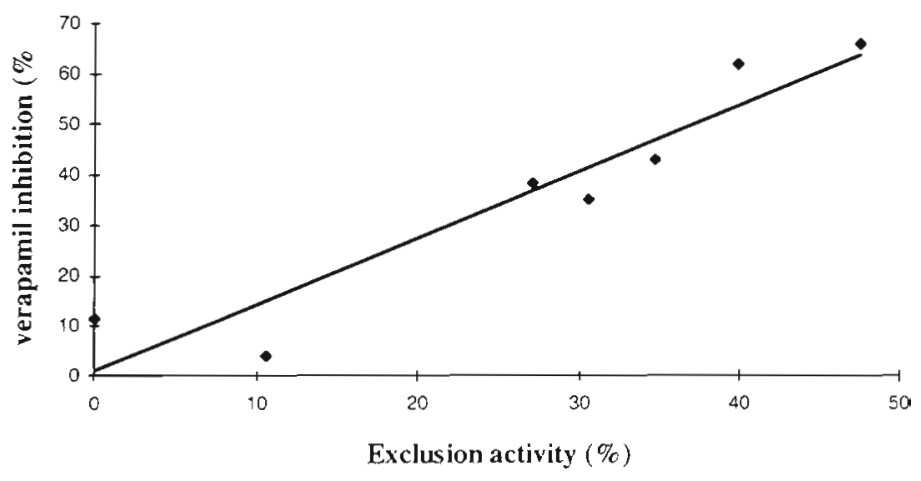

Fig. 3. Mytilus edulis Increasing effect of verapamil on blood cells with increasing rhodamine $B$ exclusion activity. Linear regression analysis give a correlation coefficient 5 of $0.89(\mathrm{p}=0.001 ; \mathrm{n}=7)$

Table 2. Mytilus edulis. Rhodamine B accumulation expressed in relative fluorescent units \pm standard deviation ( $\mathrm{n}=6$ ) in mussel blood cells incubated in a $4 \mu \mathrm{M}$ rhodamine $\mathrm{B}$ solution with or without $20 \mu \mathrm{M}$ verapamil. Results of the $t$-test between control and induced cells give $\mathrm{p}$ values under 0.05 in all cases

\begin{tabular}{|lccccc|}
\hline $\begin{array}{l}\text { Date of } \\
\text { sampling }\end{array}$ & Control cells & Exposed cells & $\begin{array}{c}\text { Decreased } \\
\text { accumulation (\%) }\end{array}$ & $\begin{array}{c}\text { Control cells } \\
\text { with verapamil }\end{array}$ & $\begin{array}{c}\text { Exposed cells } \\
\text { with verapamil }\end{array}$ \\
\hline Dec 1994 & $109.3 \pm 1.6$ & $65.7 \pm 6.3$ & 39.9 & $103.6 \pm 22.3$ & $106.3 \pm 13.2$ \\
Jan 1995 & $134.3 \pm 20.9$ & $87.7 \pm 7.3$ & 34.7 & $143.6 \pm 13.2$ & $125.3 \pm 17.4$ \\
Jan 1995 & $125.5 \pm 9.3$ & $65.8 \pm 15.2$ & 47.6 & $151.7 \pm 9.71$ & $115.5 \pm 21.7$ \\
Jun 1995 & $120.6 \pm 9.2$ & $1.07 .9 \pm 8.3$ & 10.5 & $127.3 \pm 7.9$ & $112.2 \pm 7.2$ \\
Jul 1995 & $87.8 \pm 13.9$ & $64 \pm 19.5$ & 27.1 & $88.5 \pm 15.7$ & $88.3 \pm 14.6$ \\
\hline
\end{tabular}




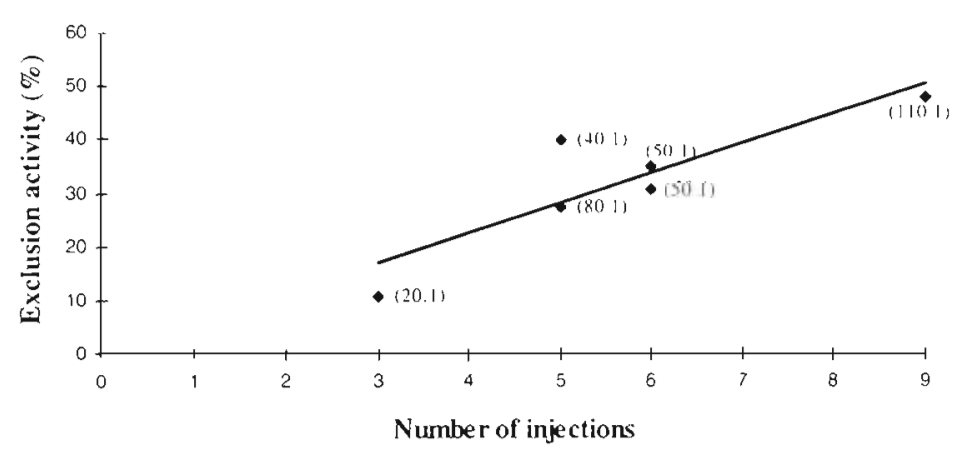

Fig. 4. Mytilus edulis. Effect of repeated injections of vincristine upon rhodamine $B$ accumulation. Linear regression analysis give a correlation brackets coefficient $r$ of $0.87(p=0.03)$. Total doses injected are indicated in

all cases but to a lesser extent in gill cells. It must be noted that the staining responses obtained with blood extracts were very weak. Only a small amount of protein was available for this experiment since it proved difficult to withdraw a large volume of blood from the damaged adductor muscles (by repeated injections) and the cell concentration in treated samples had notably decreased (data not shown) possibly as a consequence of the cytotoxic effects of the microtubule inhibitor vincristine.

\section{DISCUSSION}

a combination between vincristine concentration injected and time of exposure seems to account for the dye exclusion activity. Linear regression analysis between the number of injections and the dye exclusion activity gave a higher correlation coefficient: $r=0.87$ $(\mathrm{p}=0.026)$ (Fig. 4).

In addition, Fig. 5 shows that exposure to vincristine had a lasting effect on the rhodamine exclusion properties of the blood cells. This capacity remained stable for at least $10 \mathrm{~d}$ after the end of the treatment. Hence, no reversion of the induction was seen within that time.

\section{Expression of MXR protein}

Decreased accumulation of toxic compounds within the cell is one of the characteristics of multixenobiotic resistance. This is mainly due to the activity of a membrane protein that can be immunochemically detected in MDR cells. As this protein is largely conserved during evolution, assessment of the expression of the corresponding mussel proteins has been carried out. Fig. 6A shows the staining response obtained with protein extracts of mussel gill cells from Whitsand Bay and the Lynher estuary. Image analysis of this blot indicates that there is a significant difference in the expression level of the $170 \mathrm{kDa}$ C219 mAbdetected protein between the 2 sites ( $p<$ $0.05 ; \mathrm{n}=5$ ).

Fig. 6B shows the induction of MXR-protein expression in blood cells as the result of exposure to vincristine. Table 3 reports more completely the results of all measurements performed both on blood cells and on gill extracts. Results show that the amount of C219-detected proteins was enhanced in
The multidrug resistance (MDR) phenotype can be assessed by means of cellular accumulation of fluorescent dyes. Several different dyes have given valuable information about the ability of resistant cells to reduce their accumulation of toxic compounds compared to their 'sensitive' counterparts (Neyfakh 1988). However, few other dyes have been used as much as rhodamine, mainly because of its strong fluorescence and evidence of its sensitivity to verapamil in resistant cells. Consequently it is considered as 'a tool giving good preliminary evidence of the occurrence of the MDR phenotype' (Gottesman \& Pastan 1993). In this study we used rhodamine $B$ to stain mussel blood cells. Unlike rhodamine 123 which is reported to accumulate in mitochondria in mammalian cells (Johnson et al. 1980, Modica-Napolitano \& Aprille 1987), the unesterified rhodamine $B$ is not specific for this organelle (Johnson et al. 1981). On the contrary, the pattern of localisation (the same as neutral red) and the size of the subcellular

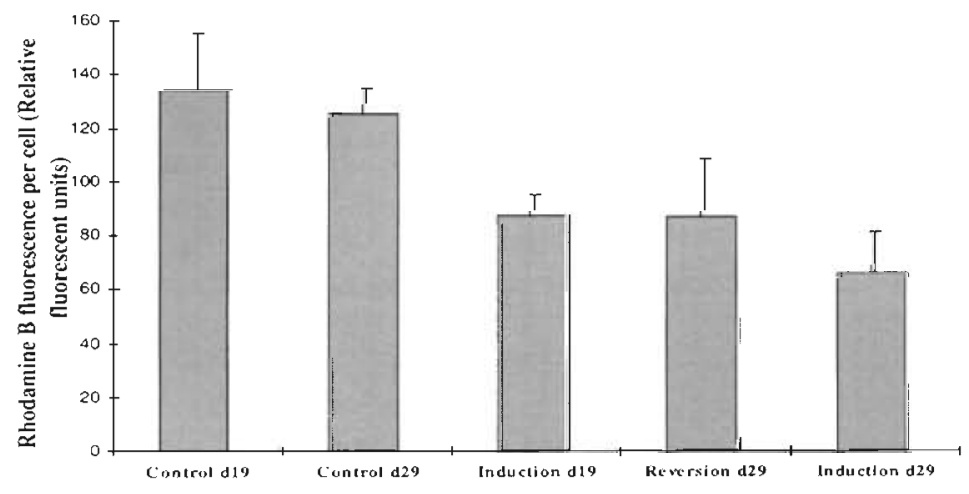

Fig. 5. Mytilus edulis. Effect of treatments with vincristine on rhodamine $\mathrm{B}$ accumulation in blood cells. Rhodamine $\mathrm{B}$ content has been assessed in non-exposed cells (control samples) and vincristine treated cells (induction and reversion samples) after 19 and $29 \mathrm{~d}$. Treated mussels received up to $10 \mathrm{\mu g}$ of vincristine every $3 \mathrm{~d}$ until Day 15 , then some mussels were left untreated (reversion samples) while the 'induction $\mathrm{d} 29^{\prime}$ samples received 3 additional injections of $20 \mu \mathrm{g}$ vincristine. Bars represent standard deviation of the mean $(n=6)$ 

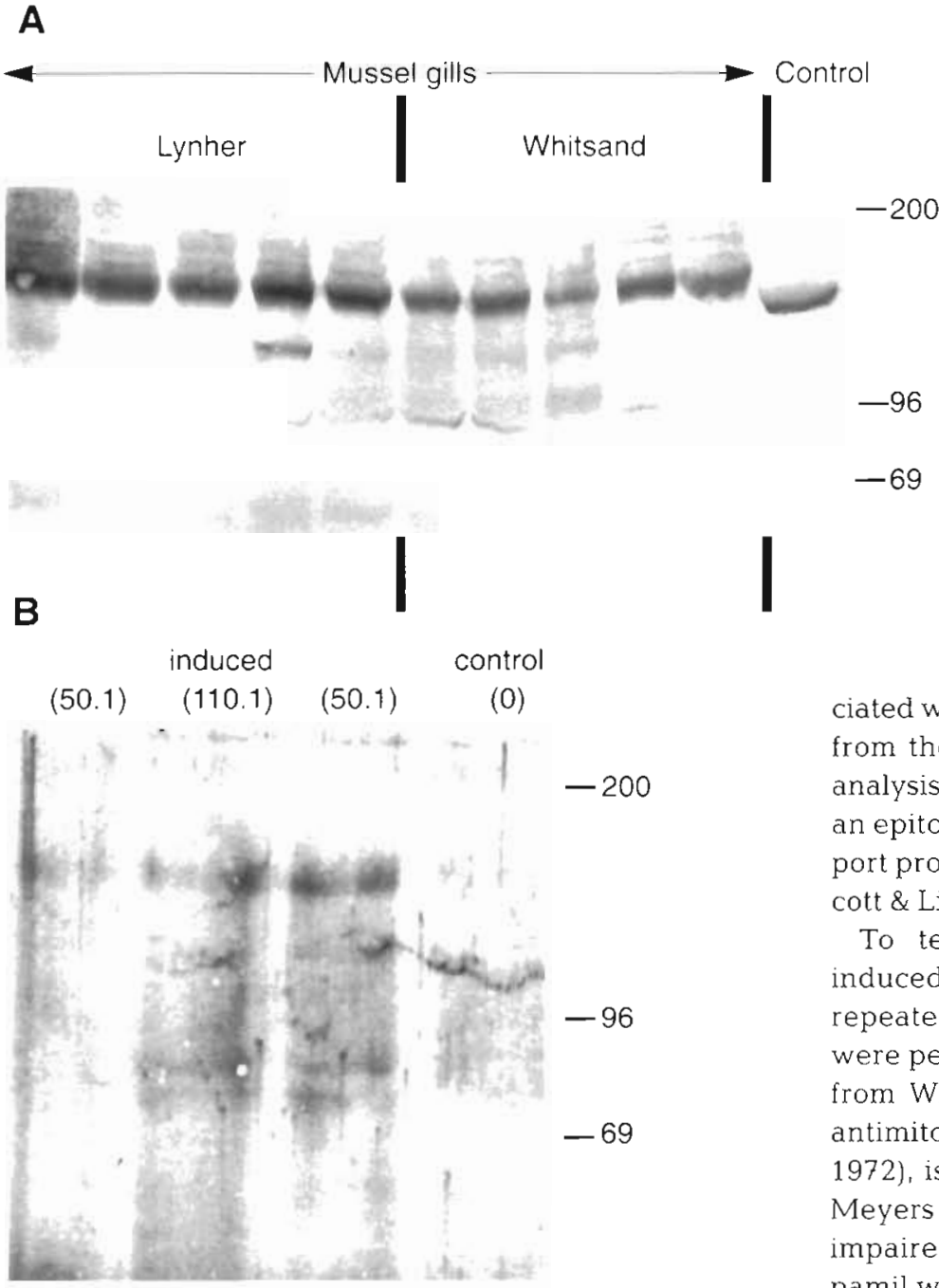

Fig. 6. Mytilus edulis. MXR protein expression in musseis $80 \mu \mathrm{g}$ of protein extract of gills from mussels living at Whitsand Bay and the Lynher estuary, and (A) $5 \mu \mathrm{g}$ of extract from control (bovine liver) and (B) $5 \mu \mathrm{g}$ of protein extract of blood cells from mussels living at Whitsand Bay and exposed to vincristine (with doses in $\mu \mathrm{g}$ in brackets) were loaded on a $9 \%$ polyacrylamide gel. Scale represents molecular weight in $\mathrm{kDa}$

component indicates that, in mussel cells, this dye accumulates in the lysosomal compartment. Moreover, incubation of the cells with verapamil, a lysosomotropic agent (Akiyama et al. 1984), induced the swelling of the rhodamine-positive organelles that then adopted a more spherical shape. A possible explanation, but not the only one, for this accumulation is the phenomon known as ion-trapping (Peterson 1979). Indeed rhodamine $\mathrm{B}$ exists in water as cationic, zwitterionic and lactonic molecular structure (Elbaraka et al. 1991). When it enters the acidic environment of the lysosomes, however, it would be converted into membrane impermeable cations that would then accumulate
Rhodamine $\mathrm{B}$ fluorescence measurements have already been used to study the MDR-like or multixenobiotic (MXR) characteristics of mussel cells (Cornwall et al. 1995). In this study measurements of rhodamine accumulation in mussel blood cells show that cells of animals sampled in a polycyclic hydrocarbon-contaminated area (the Lynher estuary) displayed an impaired dye accumulation when compared to the animals coming from a pristine area (Whitsand Bay). This lower intracellular accumulation, as in multidrug resistant cells, is verapamil sensitive, confirming similar observations made on other mussel cell types and species (Kurelec \& Pivcevic 1991, Cornwall et al. 1995, Galgani et al. 1995). Moreover, this phenotype is associated with a greater amount of MDR-like protein in cells from the Lynher estuary as detected by Western blot analysis using the C219 monoclonal antibody specific for an epitope highly conserved among the family of transport proteins that includes the MDR transporters (Endicott \& Ling 1989, Georges et al. 1990).

To test whether this MDR-like phenotype was induced by treating the animals with toxic compounds, repeated injections of the Vinca alkaloid vincristine were performed within the adductor muscle of mussels from Whitsand Bay. Vincristine, apart from being an antimitotic agent that binds to tubulin (Owellen et al. 1972), is a known inducer of MDR (Tsuruo et al. 1983, Meyers et al. 1985). Results showed that, indeed, impaired drug accumulation and sensitivity to verapamil was increased by toxic exposures and this was in accordance with previous works that showed similar impaired xenobiotic uptake sensitive to verapamil (Cornwall et al. 1995, Galgani et al. 1995). Linear regression analysis of the ability to reduce rhodamine accumulation versus the total dose injected did not

Table 3. Mytilus edulis. MXR protein expression level in blood and gill cells of vincristune-treated mussels as detected by Western blot and subsequent image analysis. Values are expressed as percentage of controls. Immunoblot performed on protein extracts from samples used for the rhodamine $B$ dssay pooled together or individuals ( $\mathrm{p}$ coefficient obtained from a $t$-test is then given, $n=6$ ); nd: not determined

\begin{tabular}{|lccc|}
\hline $\begin{array}{l}\text { Date of } \\
\text { sampling }\end{array}$ & $\begin{array}{c}\text { Vincristine } \\
\text { injected }(\mu \mathrm{g})\end{array}$ & $\begin{array}{c}\text { Staining intensity (\% of control) } \\
\text { Blood cells }\end{array}$ & Gills \\
\hline Dec 1994 & 40.1 & nd & 208 \\
Jan 1995 & 50.1 & 756 & 149 \\
Jan 1995 & 110.1 & 501 & 252 \\
Jun 1995 & 20.1 & nd & $106(p=0.045)$ \\
Jul 1995 & 80.1 & 287 & $148(p=0.072)$ \\
\hline
\end{tabular}


give a significant result ( $r=0.68, p=0.14)$. In contrast, the same test versus the number of injections did give a significant result $(\mathrm{r}=0.86, \mathrm{p}=0.026)$. This may indicate that vincristine is metabolised or excreted within at least $2 \mathrm{~d}$ of the interval between treatments. Indeed, vincristine has been reported to have a half life of about $24 \mathrm{~h}$ in human cells (Bender et al. 1977). In addition to this ability to lower the intracellular concentration of rhodamine, Western blot analysis showed an enhancement of the MXR protein expression level in treated blood cells and to a lesser extent in gill cells. These results indicate clearly that the MXR phenotype has been induced or at least that chronic exposure to vincristine has selected resistant cells. Finally, this phenotype seems to remain stable for at least $10 \mathrm{~d}$ in mussel cells and can be compared to the half life of resistance of cancer cell lines reported to be between 10 and $30 \mathrm{~d}$ depending on the growing rate of mammalian cell lines (Meyers et al. 1985)

The possible induction of MXR in marine animals is of great relevance for marine environmental research. Indeed, it has been proposed that this mechanism could be the first line of defence against environmental xenobiotics including man-made chemicals (Kurelec 1992, Cornwall et al. 1995). Reports showing the coinduction of other protective mechanisms such as the cytochrome P450 (Burt \& Thorgeirsson 1988, Pfeil et al. 1994), glutathione S-transferase (Petrini et al. 1995) and heat-shock proteins (Chin et al. 1990, Kioka et al. 1992) support this hypothesis. Consequently the MXR phenotype has the potential to become a new biomarker of exposure. Among the characteristics of the MXR phenotype, it has been suggested that verapamil sensitivity of the dye accumulation in the gills of exposed mussels could be used (Kurelec et al. 1995). This author showed that the greater the ability to decrease vincristine uptake by cells, the less verapamil sensitive they are. The inverse correlation was observed in this study. But it can be noted that different systems were used in the 2 studies: blood cells and gills. Pharmacokinetics of the dyes and drugs may differ. Furthermore, similar complexity has also been reported in mammalian cancer cells, although verapamil sensitivity remains one of the hallmarks of the MDR phenotype. For instance, verapamil was reported to fully restore daunomycin accumulation in human carcinoma cells with a wide range of degree of resistance (and consequently to increase drug accumulation accordingly to their degree of resistance) and, yet, to increase colchicine or vincristine accumulation only slightly in all cases (Fojo et al. 1985). In several studies, verapamil reversed the rhodamine accumulation in resistant cells to, or close to, the level of the their nonresistant counterparts (Altenberg et al. 1995). But this was not always the case with vincristine accumulation
(Barancik et al. 1995. Watanabe et al. 1995). These differences could be due to dissimilar affinities for the membrane-transporter or the involvement of other mechanisms. In the same report on snails, Kurelec et al. (1995) attributed the observed decrease in vincristine accumulation in snail gills to the simultaneous increase in MXR proteins. However, they also showed that the ability of the cell membranes to bind vincristine is not related to their ability to decrease the intracellular vincristine concentration. The impaired drug uptake is consequently due to a non-membrane protein-mediated mechanism. It could then involve decreased membrane permeability or decreased intracellular trapping. Two major consequences can be drawn from these observations: (1) studies on the MXR characteristics, including determination of potential substrates or modulators, are affected by the method used; and (2) the resistance mechanism in marine animals, as in mammals, could be much more complex than originally thought.

One of the more recent findings in mammal MDR is the finding of a $190 \mathrm{kDa}$ membrane protein responsible for the MDR associated protein phenomenon (MRP) (Cole et al. 1992, Zaman et al. 1994). This protein, like the $170 \mathrm{kDa}$ MDR protein, is also a member of the ABC superfamily and transfection of HeLa cells with an expression vector containing the MRP CDNA results in the acquisition of resistance to various drugs (Grant et al. 1994). Association between over-expression of the MRP protein, decreased drug accumulation and sensitivity to verapamil has been reported in several cell lines (Binaschi et al. 1995, Eijdems et al. 1995). The existence of 2 proteins associated with MDR may share some similarities with the MXR proteins of different molecular weight found in mussels. Indeed, Epel and co-workers reported the presence of 2 different proteins of 170 and $220 \mathrm{kDa}$ sharing immunochemical similarities in Mytilus galloprovincialis (Galgani et al. 1995) and only 1 of $170 \mathrm{kDa}$ in $M$. californianus (Cornwall et al. 1995). Two proteins of 220 and 240 $\mathrm{kDa}$ were previously reported in $M$. edulis (Minier et al. 1993) and in this study we found a major band at $170 \mathrm{kDa}$, and 1 or 2 faint ones at roughly $220 \mathrm{kDa}$ have been seen in other cases (Minier \& Moore unpubl. results). Although the MDR protein mobility in gel systems has been reported to be 'unusually sensitive to the conditions used' (Endicott \& Ling 1989), the possibility that several different proteins could be responsible for the occurrence of the MXR phenomon is an intriguing hypothesis.

Acknowledgements. The authors thank Drs D. Lowe and L. D Peters for their technical support and Professor B. Kurelec for his advice and comments on the manuscript. This work has been sponsored by the 'Training Through Research' programme of the European Community. 


\section{LITERATURE CITED}

Aklyama SI, Goltesman MM, Hanover JA, Fitzgerald DJP Willingham MC, Pastan I (1984) Verapamil enhances the toxicity of conjugates of epidermal growth factor with Pseodomonas exotoxin and antitransferrin receptor with Pseodomonas exotoxin. J Cell Physiol 120:271-279

Altenberg GA, Vanoye CG, Horton JK, Reuss L (1995) Changes in intra- or extracellular $\mathrm{pH}$ do not mediate Pglycoprotein-dependent multidrug resistance. Proc Natl Acad Sci CS: 1 90:9735-9738

Ames GFL, Mimura CS, Shyamala V (1990) Bacterial periplasmic permeases belong to a family of transport proteins operating from Escherichra coli to human: traffic ATPases. FEMS Microbiol Rev 75:429-446

Barancik M, Stefankova Z, Breier A (1995) Effect of phorbolmyristate (PMA) on P-glycoprotein mediated vincristine resistance of L1210 cells. Gen Physiol Biophys 14:171-175

Bender RA, Castel MC, Margileth DA, Oliveiro VT (1977) The pharmacokinetics of $\left[{ }^{3} \mathrm{H} \mid\right.$-vincristine in man. Clin Pharmacol Ther 22:430-438

Binaschi M, Supino R, De Haas M, Gambetta RA, Giaccone G Prosperi E, Capranico G, Cataldo I, Zunino F (1995) MRP gene overexpression in a human doxorubicin-resistant SCLC cell-line - alteration in cellular pharmacokinetics and in pattern of cross-resistance. Int $\mathrm{J}$ Cancer 62:84-89

Burt RK, Thorgeirsson SS (1988) Coinduction of MDR-1 multidrug-resistance and cytochrome P-450 genes in rat liver by xenobiotics. J Nat Cancer Inst 80:1383-1386

Chin KV, Tanaka S, Darlington G, Pastan I, Gottesman MM (1990) Heat shock and arsenite increase expression of the multidrug-resistance (MDR1) gene in human renal carcinoma cells. J Biol Chem 265:221-226

Cole SPC, Bhardwai G, Gerlach JH., Mackie JE, Grant CE Almquist KC, Stewart A.J, Kurz EU, Duncan AMV, Deeley RG (1992) Overexpression of a transporter gene in a multidrug-resistant human lung cancer cell line. Science 258 $1650-1654$

Cornwall R, Toomey BH, Bard S, Bacon C, Jarman WM, Epel D (1995) Characterization of multixenobiotic/multidrug transport in the gills of the mussel Mytilus californianus and identification of environmental substrates. Aquat Toxicol 31:277-296

Cornwell MM, Pastan I, Gottesman MM (1987) Certain calcium channel blockers bind specifically to multidrug-resistant human KB carcinoma membrane vesicles and inhibit drug binding to P-glycoprotein. J Biol Chem 262:2166-2170

Eijdems EWHM, Zaman GJR, De Haas $M$, Versantvoort CHM, Fens MJ, Scheper RJ, Kamst E, Borst P, Baas F (1995) Altered MRP is associated with multidrug-resistance and reduced drug accumulation in human SW-1573 cells. Br J Cancer 72:298-306

Elbaraka M, Deumie M, Viallet P, Lampidis TJ (1991) Fluorescence properties and partitionıng behaviour of esterified and unesterified rhodamines. J Photochem Photobiol 162:195-216

Endicott JA, Ling V (1989) The biochemistry of P-glycoprotein-mediated multidrug resistance. A Rev Blochem 58: $137-171$

Fojo A, Akiyama SI, Gottesman MM, Pastan I (1985) Reduced drug accumulation in multiple drug-resistant human $\mathrm{kB}$ carcinoma cell lines. Cancer Res 45:3002-3007

Galgani F, Cornwall R, Toomey BH, Epel D (1995) Interaction of environmental xenobiotics with a multixenobiotic defense mechanism in the bay mussel Mytılus galloprovincialis from the coast of California. Environ Toxicol Chem 15:325-331
Georges E, Bradley G, Gariepy J, Ling $V(1990)$ Detection of P-glycoprotein isoforms by gene-specific monoclonal antibodies. Proc Natl Acad Sci USA 87:152-156

Gottesman MM, Pastan I (1993) Biochemistry of multidrug resistance mediated by the multidrug transporter. A Rev Biochen 62:385-427

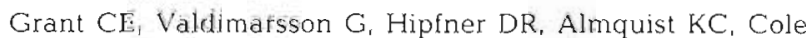
SPC, Deeley RG (1994) Overexpression of multidrugresistance-associated protein (MRP) increases resistance to natural product drugs. Cancer Res 54:357-361

Hamada $H$, Hagiwara KI, Nakijima T, Tsuruo T (1987) Phosphorylation of the $M_{\tau} 170000$ to 180000 glycoproteun specific to multidrug-resistant tumor cells: effects of verapamil, trifluoroperazine, and phorbol esters. Cancer Res $47: 2860-2865$

Higgins CF (1992) ABC transporters: from microorganisms to man. A Rev Cell Biol 8:67-113

Johnson LV, Walsh ML, Bockus BJ, Chen LB (1981) Monitoring of relative mitochondrial potential in living cells by fluorescence microscopy. J Cell Biol 88:526-535

Johnson LV, Walsh ML, Chen LB (1980) Localization of mitochondra in living cells with rhodamine 123. Proc Natl Acad Sci USA 77:990-994

Juliano RL, Ling $V(1976)$ A surface glycoprotein modulating drug permeability in Chinese hamster ovary cell mutants. Biochim Biophys Acta 455:152-162

Kioka N, Yamano Y, Komano T, Ueda K (1992) Heat shock responsive elements in the induction of the multidrugresistance gene (mdr1). FEBS Lett 301:37-40

Kurelec B (1992) The multixenobiotic resistance mechanism in aquatic organisms. Crit Rev Toxicol 19:291-302

Kurelec B, Lucic D, Pivcevic B, Krca S (1995) Induction and reversion of multixenobiotic resistance in the marine snail Monodonta turbinata. Mar Biol 123:305-312

Kurelec B, Krca S, Pivcevic B, Ugarkovic D, Bachmann M, Imsiecke G. Müller WEG (1992) Expression of P-glycoprotein gene in marine sponges: identification and characterization of the $125 \mathrm{KDa}$ drug-bınding glycoprotein. Carcinogenesis 13:69-76

Kurelec B, Pivcevic B (1991) Evidence for a multixenobiotic resistance mechanism in the mussel Mytilus galloprovincialis. Aquat Toxicol 19:291-302

Lowe DM, Soverchia C, Moore MN (1995) Lysosomal membrane responses in the blood and digestive cells of mussels experimentally exposed to fluoranthene. Aquat Toxicol 33:105-112

Lowry OH, Rosebrough NJ, Farr AL, Randall RJ (1951) Protein measurement with the folin phenol reagent. $J$ Biol Chem 193:265-275

Meyers MB, Spengler BA, Chang TD, Merera PW, Biedler JL (1985) Gene amplification-associated cytogenic aberrations and protein changes in vincristine-resistant Chinese hamster, mouse, and human cells. J Cell Biol 100: 588-597

Minier C, Akcha F, Galgani F (1993) P-glycoprotein expression in Crassostrea gigas and Mytilus edulis in polluted seawater. Comp Biochem Physiol 106: $1029-1036$

Modica-Napolitano JS, Aprille JR (1987) A basis for the selective cytotoxicity of rhodamine 123. Cancer Res 47 : $4361-4365$

Neyfakh AA (1988) Use of fluorescent dyes as molecular probes for the study of multidrug resistance. Expl Cell Res $174: 168-176$

Owellen RJ, Owens AH, Donigan DW (1972) The binding of vincristine, vinblastine and colchicine to tubulin. Biochem Blophys Res Commun 47:685-691 
Peterson CA (1979) Selective vital staining of companion cells of potato tuber and parsmip root with Neutral Red. Stain Technol 54:135-139

Petrini M, Disimone D, Favati A, Mattii L, Valentini P, Grass B (1995) GST-pi and P-170 coexpression in multiple myeloma. Br J Haematol 54:135-139

Pfeil D, Bergmann J, Fichtner I, Stein U, Hentschel M, Rohte I. Goan SR (1994) Multidrug-resistance of murine leukemia cells characterization and correlation with cytochrome P-450 dependant activities, cytosolic calcium and cell cycle state. Anticancer Res 14:571-576

Readman JW, Mantoura RFC, Rhead MM, Brown L (1982) Aquatic distribution and heterotrophic degradation of polycyclic aromatic hydrocarbons (PAH) in the Tamar estuary. Estuar Coast Shelf Sci 14:369

Riordan JR, Ling V (1985) Genetic and biochemical characterization of multidrug resistance. Pharmacol Ther 28:51-75

Tapeiro H, Munck JN, Fourcade A, Lampidis TJ (1984) Crossresistance to rhodamine 123 in adriamycin- and daunorubicin-resistant Friend leukemia cell variants. Cancer Res $44: 5544-5549$

Toomey BH (1995) A multixenobiotic defense mechanism in the embryos of the Echyurian worm Urechis caupo. $\mathrm{PhD}$ thesis, Stanford University, Palo Alto, CA

Toomey BH, Epel D (1993) Multidrug resistance in Urechis

This article was submitted to the editor caupo embryos: protection from environmental toxins. Biol Bull 185:355-364

Tsuruo T, Iida H, Nojiri M, Tsukagoshi S, Sakurai Y (1983) Circumvention of vincristine and adriamycin resistance in vitro and in vivo by calcium influx blockers. Cancer Res 43:2905-2910

Waldmann P, Pivcevic B, Müller WEG, Zahn RK, Kurelec B (1995) Increased genotoxiclty of acetylaminofluorene by modulators of multixenobiotic resistance mechanism: studies with the fresh water clam Corbicula fluminea. Mutat Res 342:113-123

Watanabe $T$, Tsuge $H$, Ohhara $T$, Naito M, Tsuruo $T$ (1995) Comparative study on reversal efficacy of SDZ PSC-833. cyclosporine $\mathrm{A}$ and verapamil on multidrug resistance in vitro and in vivo. Acta Oncol 34:235-241

Widdows J, Donkin P, Brinsley MD, Evans SV, Salkeld PN, Franklin A, Law RJ, Waldock MJ (1995) Scope for growth and contaminant levels in North Sea mussels Mytilus edulis. Mar Ecol Prog Ser 127:131-148

Zaman GJR, Flens MJ, Van Leusden MR, De Haas M, Mülder HS, Lankelma J, Pinedo HM, Scheper RJ, Baas F, Broxterman HJ, Borst P (1994) The human multidrug resistance-associated protein MRP is a plasma membrane drug-efflux pump. Proc Natl Acad Sci USA 91 $8822-8826$

Manuscript first received: March 7, 1996

Revised version accepted: August 9, 1996 